\title{
COMMENT
}

\section{IMPEACHING A DEFENDANT'S TRIAL TESTIMONY BY PROOF OF POST-ARREST SILENCE}

Since the Supreme Court's decision in Miranda $v$. Arizona, ${ }^{1}$ the government has been required to establish, as a prelude to introducing in evidence any statement made by a defendant during custodial interrogation, that prior to making the statement the defendant was advised of his right to remain silent and of his right to the presence of counsel. In formulating this prophylactic rule, the Court was attempting to ensure, by a means less cumbersome than a case-by-case due process inquiry into voluntariness, ${ }^{2}$ that any self-incriminating statement used against a criminal defendant be the product of his free will following a knowing and intelligent waiver of fifth and sixth amendment rights. Miranda's exclusionary rule was obviously aimed at protecting the defendant who makes a statement to police: If the warnings are not given, the statement may not be used as substantive evidence. But what of the defendant who, warned of his constitutional rights, makes no statement to police and declines to respond to police questioning? ${ }^{3}$ Does he derive any protection from the fifth amendment prohibition against compelled self-incrimination?

The constitutionality of using post-arrest silence to impeach a defendant's credibility has been litigated several times in the

1384 U.S. 436 (1966).

${ }^{2}$ Se', '-g., Spano v. New York, 360 U.S. 315 (1959); $f f$. McNabb v. United States, 318 U.S. 332 (1943).

${ }^{3}$ Empirical studies indicate that a significant proportion of arrestees, after receiving the Miranda narnings. exercise their right to remain silent. The percentages have varied from $40 \%$ in Pittsburgh, Seeburger \& Wettick, Miranda in Pittsburgh-A Statistical Study, 29 U. Prtr. L. Rev. 1, 13 (1967), to 60\% in Washington, D.C., Medalie, Zeitz \& Alexander. Cuslodial Police Interrogation in Our Nation's Capital: The Attempt to Implement Miranda, 66 Mich. L. Rev. 1347, 1372, 1414 (1968); $f$. Leiken. Police Interrogation in Colorado: The Implementation of Miranda, 47 DExver L.J. 1, 13 (1970). But cf. Comment, Interrogations in New Haven: The Impact of Miranda, 76 Y ALE L.J. 1519, 1563 (1967) (disputing the proposition that warnings produced less talking by arrestees than would have been the case without the warnings). 
years since Miranda. The results have been diverse. Typically, the defendant takes the witness stand at his trial and offers an alibi defense or other exculpatory testimony. On cross-examination, the prosecutor elicits that defendant did not tell the exculpatory story to the police when he was arrested. The prosecutor argues in his summation that the jury should disbelieve defendant's exculpatory trial testimony because, if it were true, he would have protested the fact to the police when first arrested and charged with the crime.

This problem presents a direct conflict between the fifth amendment concerns underlying the Court's decision in Griffin $v$. California ${ }^{4}$ and the government's interest in truthful and accurate testimony. The importance of the latter was recognized in the impeachment exception to the Miranda exclusionary rule enunciated in the later decision of Harris $v$. New York. ${ }^{5}$ The courts that have faced this issue have not agreed upon the proper accommodation to be made between the rationales of the two decisions. Cases in the Third and Fifth Circuits have sanctioned impeachment use of a defendant's post-arrest silence as a legitimate aid to testing the truthfulness of his trial testimony, ${ }^{6}$ while cases in the Tenth and District of Columbia Circuits have proscribed its use as a penalty upon the exercise of the fifth amendment privilege. ${ }^{7}$ The problem was treated recently in the Third Circuit case of Agnellino $v$. New Jersey. ${ }^{8}$ A sharp division among the members of the panel resulted in the fullest discussion of the question to date, and provides a framework for exploring the reaches of Griffin and Harris.

Consideration will first be given to the Court's decisions in Griffin and Harris and to the conflicting applications of those doctrines to the arrest silence issue by the courts of appeals. Attention will then shift to Agnellino itself and to an examination of the treatment accorded Griffin and Harris by the court in that case, followed in each instance by a critical analysis of that treatment. A suggested resolution of the problem of impeachment use of arrest silence will emerge.

4380 L'S. 609 (1965); see text accompanying notes 9-14 infra.

: 401 L.S. 222 (1971); see text accompanying notes $21-25$ infra.

6 Lnited States ex rel. Burt v. New Jersey, 475 F.2d 234 (3d Cir.), cert. denied, 414 L.S. 938 (1973); United States v. Ramirez, 441 F.2d 950 (Jth Cir.), cert. denied, 404 L.S. 869 (1971).

- United States v. Anderson, 498 F.2d 1038 (D.C. Cir.), cert. granted sub nom. United States v. Hale, 9j S. Ct. 616 (1974) (No. 74-364); Johnson v. Patterson, 475 F.2d 1066 (10th Cir.). cert. denied, 414 U.S. 878 (1973).

s 493 F.2d 714 (3d Cir. 1974). 


\section{BACKGROUND: GRIFFIN, HARRIS, AND THE IMPEACHMENT DECiSIONS}

The argument that impeachment use of a defendant's silence upon arrest violates the fifth amendment is bottomed upon the Court's decision in Griffin $v$. California. ${ }^{9}$ At the trial, the prosecutor had urged an inference of guilt from Griffin's failure to take the stand. ${ }^{10}$ Moreover, the trial court had instructed the jury that the defendant's failure to deny or explain evidence which he "can reasonably be expected to deny or explain because of facts within his knowledge" may indicate that "among the inferences that may be reasonably drawn therefrom those unfavorable to the defendant are the more probable." 11 The Supreme Court reversed the conviction, articulating this standard:

[C]omment on the refusal to testify is a remnant of the 'inquisitorial system of criminal justice,' . . . which the Fifth Amendment outlaws. It is a penalty imposed by courts for exercising a constitutional privilege. It cuts down on the privilege by making its assertion costly. ${ }^{12}$

The Court's reliance upon the "penalty" rationale to establish the no-comment rule was a clear departure from traditional fifth amendment "compulsion" analysis. ${ }^{13}$ Because the defendant

" 380 U.S. 609 (1965).

${ }^{10}$ As early as 1893 , the Court held that comment upon a defendant's failure to testify is reversible error in a federal prosecution. Wilson v. United States, 149 U.S. 60 (1893). That holding was based upon a federal statute, now codified as 18 U.S.C. $\S 3481$ (1970), so it provided no precedent for the constitutional holding reached in Griffin. Prior to Griffin, the Court twice faced the constitutional issue, but did not reach the question either time because the fifth amendment was not held applicable to the states. Adamson v. California, 332 U.S. 46 (1947); Twining v. New Jersey, 211 U.S. 78 (1908). In 1964, however, the Court held that the fifth amendment privilege against self-incrimination is binding upon the states through the fourteenth amendment and that the same fifth amendment standards apply in state as in federal proceedings. Malloy v. Hogan, 378 U.S. 1 (1964). Justice Douglas, writing for the majority in Griffin a year later, was thus able to hold the California practice unconstitutional. 380 U.S. at 614-15. Cf. Adamson v. California, supra at 90 (Black, J., dissenting, joined by Douglas, J.); id. at 124-25 (Murphy, J., dissenting, joined by Rutledge, J.) (would hold fifth amendment applicable to the California practice); id. at 61 (Frankfurter, $\mathrm{J}$., concurring) (implying that the fifth amendment would be applicable but for the barrier of fourteenth amendment jurisprudence).

11380 U.S. at 610 . The prosecutor's comment and the court's instruction were authorized by the California constitution. Id. n.2.

${ }^{12} I d$. at 614 .

${ }^{13}$ Justice Stewart dissented:

[T] $\mathrm{T}$ he Court in this case stretches the concept of compulsion beyond all reasonable bounds... Exactly what the penalty imposed consists of is not 
had neither taken the stand nor given the police a statement before trial, there was no question of compelled self-incrimination and the decision could not have been justified upon that basis. ${ }^{14}$ Thus, the Court engrafted onto the fifth amendment as previously understood the additional proscription that no inference of guilt be urged from a defendant's assertion of the privilege at trial.

The initial constitutional challenges to use of a defendant's silence upon arrest were directed at substantive use of that evidence in the prosecution's case in chief, ${ }^{15}$ rather than at the more limited use of impeaching the credibility of a defendant who takes the stand in his own defense. The consistent holding of all courts which have faced the issue has been that such use of an accused's post-arrest silence as evidence of guilt violates the fifth amendment privilege against self-incrimination. ${ }^{16}$ Un-

clear. . . Since comment by counsel and the court does not compel testimony by creating such an awareness, the Court must be saying that the California constitutional provision places some other compulsion upon the defendant to incriminate himself, some compulsion which the Court does not describe and which I cannot readily perceive.

Id. at 620-21 (Stewart, J., dissenting). See also 8 J. Wigmore, Evidence $\S \S 2250-51$, at 284-95, 315-18 (McNaughton rev. 1961); Graper, The Origins of the Privilege Against Self-Accusation-An Introduction, 16 U. PITT. L. Rev. 339, $341-43$ (1955).

${ }^{14}$ See Friendly, The Fifth Amendment Tomorrow: The Case for Constitutional Change, 37 U. Cin. L. Rev. 671, 700 (1968); The Supreme Court, 1964 Term, 79 HaRv. L. Rev. 56, 159-60 (1965); Note, 70 Dick. L. Rev. 98 (1965). See also C. McCormick, HandBOOK OF THE LAW OF EvideNCE § 131, at 275-78 (2d ed. 1972).

${ }^{15}$ McCarthy v. United States, 25 F.2d 298 (6th Cir. 1928), appears to be the first in which the issue was raised.

${ }^{16}$ United States v. Faulkenbery, 472 F.2d 879 (9th Cir.), cert. denied, 411 U.S. 970 (1973); United States v. Nolan, 416 F.2d 588 (10th Cir.), cert. denied, 396 U.S. 912 (1969); Cockrell v. Oberhauser, 413 F.2d 256 (9th Cir. 1969), cert denied, 397 U.S. 974 (1970); United States v. Nielsen, 392 F.2d 849 (7th Cir. 1968); United States v. Mullings, 364 F.2d 173 (2d Cir. 1966); Helton v. United States, 221 F.2d 338 (5th Cir. 1955); McCarthy v. United States, 25 F.2d 298 (6th Cir. 1928); $c f$. United States ex rel. Macon v. Yeager, 476 F.2d 613 (3d Cir.), cert. denied, 414 U.S. 855 (1973) (testimony that defendant exercised his right to counsel upon arrest violates the sixth amendment). The distance between Griffin and the use of post-arrest silence as substantive evidence of guilt is obviously slight. After 1965, the courts relied explicitly on Griffin. See, e.g., United States v. Kroslack, 426 F.2d 1129, 1130 (7th Cir. 1970); United States v. Nolan, 416 F.2d 588, 594 (10th Cir.), cert. denied, 396 U.S. 912 (1969). Some pre-Griffin cases relied upon a similar line of reasoning. See Helton v. United States, 22 I F.2d 338, 341-42 (5th Cir. 1955); McCarthy v. United States, 25 F.2d 298, 299 (6th Cir. 1928). Some courts bolstered their holdings by referring to language from Miranda v. Arizona, 384 U.S. 436, 468 n.7 (1966), that indicated that the majority in that case considered such use to be unconstitutional:

In accord with our decision today, it is impermissible to penalize an individual for exercising his Fifth Amendment privilege when he is under police custodial interrogation. The prosecutor may not, therefore, use at trial the fact that he stood mute or claimed the privilege in face of accusa- 
daunted, prosecutors began urging that evidence of silence upon arrest should nevertheless be admissible on the issue of credibility when the defendant takes the stand and makes statements "inconsistent" with the prior silence. Prior to 1971, however, the Supreme Court had recognized only a very limited impeachment exception to the exclusionary rules-and that only

tion. Cf. Griffin v. California, 380 U.S. 609 (1965); Malloy v. Hogan, 378 U.S.

$1,8(1964) \ldots$

Application of Griffin to cases involving use of post-arrest silence as evidence of guilt can hardly be questioned on logical grounds. In both cases the government urges the jury to infer guilt from an assertion of the privilege against self-incrimination. The sole distinction-that Griffin involved silence at trial, whereas the latter cases involved silence upon arrest-does not suggest a difference in result. On the contrary, an inference of guilt from silence during custodial interrogation, where the procedural safeguards of a trial are lacking, would be even more tenuous than such an inference from silence at trial.

The little comment evoked by cases proscribing use of silence as evidence of guilt has generally been favorable. See Note, 7 BayLor L. REv. 447 (1955); Note, 10 WASHBURN L.J. 105 (1970). Even those courts which have approved the use of silence to impeach the testimony of a defendant have supported the prohibition against its use to establish guilt. The Third and Fifth Circuits, for example, are among jurisdictions holding that a defendant's silence upon arrest is a proper subject for crossexamination and argument when the defendant takes the stand. United States ex rel. Burt v. New Jersey, 475 F.2d 234 (3d Cir.), cert. denied, 414 U.S. 938 (1973); United States v. Ramirez, 441 F.2d 950 (5th Cir.), cert. denied, 404 U.S. 869 (1971). Yet the law of these circuits is clearly that such silence is constitutionally inadmissible on the question of guilt. United States ex rel. Smith v. Brierly, 384 F.2d 992 (3d Cir. 1967); Walker v. United States, 404 F.2d 900 (5th Cir. 1968).

Under certain circumstances, the courts have declined to apply the principle when the accused was shown not to have been under custodial interrogation at the time of his silence. Miller v. Cox, 457 F.2d 700, 703 (4th Cir.), cert. denied, 409 U.S. 1007 (1972). But see Walker v. United States, 404 F.2d 900 (5th Cir. 1968) (testimony that defendant had asserted fifth amendment privilege in noncustodial confrontation with the owner of goods allegedly stolen by defendant is inadmissible as evidence of guilt). Similarly, the principle has been unused when the defendant made a statement but omitted certain material elements. United States v. Moore, 484 F.2d 1284, 1286 (4th Cir. 1973); United States v. Cordova, 421 F.2d 471, 474 (9th Cir.), cert. denied, 398 U.S. 941 (1970). The Eighth Circuit appears to have gone even further, holding that when the defendant maintains total silence at first, but later makes a statement, the silence can be used against him. United States v. Briddle, 443 F.2d 443,448 (8th Cir.), cert. denied, 404 U.S. 942 (1971). Some courts have declined to reverse when defense counsel invited the error, United States ex rel. Coffey v. Follette, 423 F.2d 750 (2d Cir. 1970), aff'g per curiam 310 F. Supp. 946, 949 (S.D.N.Y. 1969); United States v. White, 377 F.2d 908, 911 (4th Cir.), cert. denied, 389 U.S. 884 (1967), or failed to make a timely objection to its use, United States v. Cook, 432 F.2d 1093, 1103 (7th Cir. 1970), cert. denied, 401 U.S. 996 (1971); Laughlin v. United States, 411 F.2d 1224, 1225 (9th Cir. 1969), cert. denied, 396 U.S. 1021 (1970); Hayes v. United States, 407 F.2d 189, 194-95 (5th Cir.), cert. dismissed, 395 U.S. 972 (1968). But see United States v. Arnold, 425 F.2d 204, 206 (10th Cir. 1970); United States v. Nolan, 416 F.2d 588, 594 (10th Cir.), cert. denied, 396 U.S. 912 (1969), where the Tenth Circuit reached the use of silence issue despite lack of contemporaneous objection below, because it deemed the use of post-arrest silence as evidence of guilt "error ... so plain, fundamental, and serious" that it could not be overlooked. The courts 
in the fourth amendment context. ${ }^{17}$ Although that impeachment doctrine had been extended somewhat by the lower federal courts, ${ }^{18}$ the argument for impeachment use of a defendant's silence upon arrest was rarely successful. There were a few exceptions, ${ }^{19}$ mostly in state courts, but the federal courts generally held constitutionally impermissible the impeachment of a defendant's exculpatory trial testimony by proof that he had been silent when arrested. ${ }^{20}$ The courts reasoned that impeachment use was similar to use to show guilt: It placed a penalty upon the exercise of the right to remain silent.

In 1971, the Supreme Court handed down its decision in Harris v. New York, ${ }^{21}$ applying in the fifth amendment context a greatly expanded version of the impeachment exception of Walder $v$. United States. ${ }^{22}$ Harris had been charged with making two sales of heroin to an undercover police officer. At trial he took the stand and denied making one of the sales. He admitted having made the second sale, but testified that the bag contained

have also refused to reverse where, as a result of an objection, the testimony was stricken from the record, United States v. Castaldi, 453 F.2d 506, 511 (7th Cir. 1971), cert. denied, 405 U.S. 992 (1972), or made the subject of a cautionary instruction to the jury, Hayes v. United States, 407 F.2d 189, 195 (ath Cir.), cert. dismissed, 395 U.S. 972 (1909); Spears v. United States, 281 A.2d 287, 290 (D.C. 1971); Grimes v. State, 280 N.E.2d 575, 579 (Ind. 1972); Buckner v. State, 56 Wis. 2d 539, 549, 202 N.W.2d 406, 412 (1972). In some cases, permitting evidence of or comment upon defendant's silence was held, in view of other overwhelming evidence of guilt, harmless constitutional error. United States v. King, 485 F.2d 353, 360 (10th Cir. 1973); State v. Geter, 108 R.I. 437, 442-43, 276 A.2d 274, $276-77$ (1971). See generally Chapman v. California, 386 U.S. 18 (1967).

None of these cases, however, questioned the rule that the fifth amendment is violated by the use of a defendant's post-arrest assertion of the privilege against selfincrimination as evidence of guilt.

17 Walder v. United States, 347 U.S. 62 (1954), held that a defendant who takes the stand and in his testimony goes beyond a mere denial of complicity in the crime charged and makes a "sweeping claim" concerning collateral matters may be impeached by evidence inadmissible under the fourth amendment. The Court was careful to distinguish a prior case, Agnello v. United States, 269 U.S. 20 (1925), where on direct examination the defendant had not testified in such a manner as to open the door to the use of the illegally obtained evidence. 347 U.S. at 66 .

${ }^{18}$ See, e.g., United States v. Curry, 358 F.2d 904, 909-12 (2d Cir.), cert. denied, 385 U.S. 873 (1966); Tate v. United States, 283 F.2d 377, 378-80 (D.C. Cir. 1960) (both allowing impeachment by unlawfully obtained statements).

19 Sharp v. United States, 410 F.2d 969 (5th Cir. 1969); Johnson v. People, 172 Colo. 406, 473 P.2d 974 (1970); State v. Jackson, 201 Kan. 795, 443 P.2d 279 (1968), cert. denied, 394 U.S. 908 (1969); May v. State, 21 I So. 2d 845 (Miss. 1968).

${ }^{20}$ United States v. Brinson, 411 F.2d 1057 (6th Cir. 1969); Fowle v. United States, 410 F.2d 48 (9th Cir. 1969); Fagundes v. United States, 340 F.2d 673 (1st Cir. 1965); cf. State v. Galasso, 217 So. 2d 326 (Fla. 1968).

21401 U.S. 222 (1971).

22347 U.S. 62 (1954); see note 17 supra. 
only baking powder. On cross-examination the government was permitted to impeach his testimony by showing that a statement obtained in violation of Miranda was inconsistent with his trial testimony. Purporting to rely upon Walder, the Court held that even a statement obtained in violation of Miranda may be used to impeach a defendant's testimony, provided its trustworthiness "satisfies legal standards." 23 The Court acknowledged that the impeachment evidence in Walder regarded collateral matters, whereas the testimony in Harris was related "more directly [to] the crimes charged"; but it saw no "difference in principle" requiring a result contrary to that reached in Walder. ${ }^{24}$ The Court's concluding statement summarized the policy underlying the Harris decision:

Every criminal defendant is privileged to testify in his own defense, or to refuse to do so. But that privilege cannot be construed to include the right to commit perjury. . . Having voluntarily taken the stand, petitioner was under an obligation to speak truthfully and accurately, and the prosecution here did no more than utilize the traditional truth-testing devices of the adversary process. ...

The shield provided by Miranda cannot be perverted into a license to use perjury by way of a defense, free from the risk of confrontation with prior inconsistent utterances. We hold, therefore, that petitioner's credibility was appropriately impeached by use of his earlier conflicting statements. ${ }^{25}$

In the years since Harris, courts have been increasingly willing to allow impeachment use of post-arrest silence. Ramirez v. United States ${ }^{\mathbf{2 6}}$ was the first case following Harris to present the issue to a court of appeals. ${ }^{27}$ In Ramirez the defendant had

23401 U.S. at 224.

${ }^{24}$ Id. at 225. The Harris decision has been the subject of vigorous criticism, largely because of this sub silentio overruling of the Walder limitation on the impeachment exception to the exclusionary rule. See Dershowitz \& Ely, Harris v. New York: Some Anxious Observations on the Candor and Logic of the Emerging Nixon Majority, 80 YALE L.J. 1198 (1971); Kent, Harris v. New York: The Death Knell of Miranda and Walder?, 38 Brooklyn L. Rev. 357 (1971); 39 Geo. Wash. L. Rev. 1241 (1971); 24 Vand. L. Rev. 843 (1971).

25401 U.S. at $225-26$.

26 441 F.2d 950 (5th Cir.), cert. denied, 404 U.S. 869 (1971).

${ }^{27}$ Since the decision in Harris, the appellate courts of several states have also had occasion to decide the impeachment use of silence issue. Most state courts have held impeachment use of arrest silence to be impermissible. State v. Anderson, 110 Ariz. 238, 5I7 P.2d 508 (1973); Hines v. People, 497 P.2d 1258 (Colo. 1972); People 
been arrested and charged with dealing in heroin. He did not dispute the factual allegations of the indictment, but raised the defense of coercion, testifying that he had sold heroin only because a group of men from Mexico had threatened him with immediate bodily harm if he refused to cooperate. Government counsel cross-examined Ramirez regarding his having remained silent upon arrest, and in closing argument urged the jury to disbelieve his testimony because "a man actually under duress and fearful for his family's safety would have informed the police of such a dangerous situation upon being apprehended." 28 The Fifth Circuit held that impeachment use of Ramirez's postarrest silence was constitutionally permissible, reasoning that the "analogy of Harris to the case at hand is inescapable.""9 Prior Fifth Circuit cases which had invoked Griffin's penalty doctrine to prevent guilt use of post-arrest silence ${ }^{30}$ were neither distinguished nor cited. The court was apparently content to read Harris as having resolved any possible objection to impeachment by proof of prior silence.

The issue of impeachment use of silence upon arrest was raised in a slightly different factual context in United States ex rel. Burt $v$. New Jersey. ${ }^{31}$ Defendant Burt was arrested on a charge of breaking and entering but, unknown to the police, had been involved in the shooting of a friend, one Owens, the night before the arrest. While Burt was in custody on the breaking and entering charge, the police were informed of the shooting and of Burt's alleged involvement. At his trial for murder, Burt took the stand and testified that the shooting had been accidentalthe result of an argument and ensuing struggle between Owens and himself. On cross-examination the prosecutor asked him

v. Bobo, 390 Mich. 355, 212 N.W.2d 190 (1973) (overruling a line of decisions in the intermediate appellate courts of Michigan which had permitted impeachment use of post-arrest silence); State v. Griffin, 120 N.J. Super. 13, 292 A.2d 217, certif. denied, 62 N.J. 73, 299 A.2d 328 (1972). Contra, People v. Queen, 8 Ill. App. 3d 858, 290 N.E.2d 631 (1972); Thomas v. State, 285 So. 2 d 148 (Miss. 1973), cert. denied, 95 S. Ct. 44 (1974). In Florida the law is unclear. A pre-Harris case disallowed impeachment use of post-arrest silence, State v. Galasso, 217 So. $2 d 326$ (Fla. 1968), but a postHarris case has reversed Galasso "to the extent that [it is] inconsistent with Harris." State v. Ratherford, 270 So. 2d 363, 364-65 (Fla. 1972), cert. denied, 412 U.S. 953 (1973). It is uncertain at this point whether the court considers banning impeachment use of silence to be inconsistent with Harris.

28441 F.2d at 954.

${ }^{29} I d$. The soundness of the court's conclusion that Harris controls the impeachment use of silence issue is discussed in text accompanying notes 98-140 infra.

${ }^{30}$ Walker v. United States, 404 F.2d 900 (5th Cir. 1968); Helton v. United States, 221 F.2d 338 (5th Cir. 1955).

31475 F.2d 234 (3d Cir.), cert. denied, 414 U.S. 938 (1973). 
why he had neither sought aid for his wounded friend nor informed anyone of his condition, to which he had no response. In his summation the prosecutor referred to Burt's failure to tell anyone what had happened, arguing that if the shooting had been accidental, Burt would have tried to obtain help for the injured Owens.

The Third Circuit, in a per curiam opinion, held that the cross-examination and argument had not violated the fifth amendment. The decision was based upon the narrow ground that Burt's silence was not "in the face of accusation"32-he was not accused of murder when taken into custody, but of breaking and entering-so that "the basis for the necessity of Fifth Amendment protection did not exist in the ... situation." ${ }^{33}$ The concurring opinion of two members of the three-judge panel, however, viewed the facts as raising the issue of comment upon silence in the face of the accusation, because Burt was in custody at the time the police began to suspect him of the murder and, at least from that point forward, his failure to tell police of the accidental shooting was silence "in the face of accusation." 34 The concurring opinion relied upon Harris as permitting impeachment by proof of a defendant's post-arrest silence, of "testimony which is contradictory to his earlier silence,"35 and found the Griffin penalty doctrine no bar to the impeachment use of silence because of waiver ${ }^{36}$ and lack of

32 The distinction derives from the Miranda dictum quoted in note 16 supra.

${ }^{33} 475$ F.2d at 236.

${ }^{34}$ Id. at 237 (Rosenn, J., concurring, joined by Van Dusen, J.). One district court has read Burt as permitting impeachment use of silence upon arrest only when the silence was with respect to matters other than the charge against the defendant. United States v. Holland, 360 F. Supp. 908, $911-12$ (E.D. Pa.), aff'd, 487 F.2d 1395 (3d Cir. 1973). See Agnellino v. New Jersey, 493 F.2d 714, 728 (3d Cir. 1974) (Seitz, C.J., concurring) (would give Burt this same limited reading). But the concurring opinion in Burt, in which two of the judges on the panel joined, should be read as stating the law of the case-that impeachment use may be made of a defendant's silence upon arrest with respect to the crime charged. See Agnellino v. New Jersey, supra at 718-19 (so reading $B$ urt).

35 475 F.2d at 237 (Rosenn, J., concurring).

${ }^{36} I d$. at 238 . The concept of waiver relied upon in this context is a curious one, because it is necessarily a retroactive waiver. The argument is that when defendant takes the stand he waives the prior assertion of the privilege, made at the time of the arrest. Some courts have viewed the situation from the opposite perspective and have argued that to permit the defendant to testify at trial would be to sanction a "partial waiver" of the privilege. See, e.g., United States v. Anderson. 498 F.2d 1038, 1047-48, 1051 (D.C. Cir.) (Wilkey, J., dissenting), cert. granted sub nom. United States v. Hale, 95 S. Ct. 616 (1974) (No. 74-364); Johnson v. Patterson, 475 F.2d 1066, 1069 (10th Cir.) (Breitenstein, J., dissenting), cert. denied, 414 U.S. 878 (1973). Reliance is placed upon Raffel v. United States, 271 U.S. 494 (1926), which held that a defendant who takes the 
compulsion. ${ }^{37}$

Counterpoised against the holdings of these two circuits is a Tenth Circuit case, Johnson v. Patterson, ${ }^{38}$ which was the first case in the courts of appeals since Harris to disallow impeachment use of post-arrest silence. ${ }^{39}$ Defendant Johnson stood accused of rape. At his trial he took the stand and testified to the defense of consent, explaining that the complaining witness had been caught trying to steal his car and had offered to have intercourse in return for his promise not to report the attempted theft. During cross-examination, government counsel elicited that Johnson had not told this story to police when arrested, and referred to the silence again in his closing argument. Relying upon Griffin, the Miranda dictum, and its own prior guiltuse cases, ${ }^{40}$ the court held the use of a defendant's arrest silence to impeach his trial testimony to be impermissible as a "penalty on the exercise of a constitutional right." 41 The court thought Harris inapplicable to a situation involving prior silence, as opposed to a prior inconsistent statement. ${ }^{42}$

In accord with Johnson is United States $v$. Anderson, ${ }^{43}$ the most recent case raising the issue of impeachment use of silence. The court relied primarily upon the lack of probative value of a de-

stand waives his privilege "completely" and cannot object to cross-examination which discloses that he had previously asserted the privilege in the face of testimony similar to that which he now denies. It is doubtful, however, whether this doctrine is viable today. Grunewald v. United States, 353 U.S. 391, 418-21 (1957), id. at 425-26 (Black, J., concurring); see C. McCormick, supra note 14, § 132, at 281 \& n.44. The doctrine predates the modern era of constitutional criminal procedure and should not be considered to have resolved the conflict between the penalty doctrine and the impeachment exception to the Miranda exclusionary rule. $C f$. note 73 infra.

${ }^{37} 475$ F.2d at 239. The argument that impeachment use of silence is not impermissible under Griffin because it does not compel the defendant under traditional standards misconceives the noncompulsion basis of the Griffin holding. See notes 13-14 supra \& accompanying text.

38475 F.2d 1066 (10th Cir.), cert. denied, 414 U.S. 878 (1973), noted in 87 HaRv.

L. Rev. 882 (1974), 33 MD. L. Rev. 363 (1973), and 5 U. ToL. L. Rev. 381 (1974).

3:" For state court cases which have disallowed impeachment use of post-arrest silence, see note 27 supra.

${ }^{40}$ United States v. Arnold, 425 F.2d 204 (10th Cir. 1970); United States v. Nolan, 416 F.2d 588 (10th Cir.), cert. denied, 396 U.S. 912 (1969); cf. United States v. Julian, 450 F.2d 575 (10th Cir. 1971).

4475 F.2d at 1067.

42 Id. at 1068. Judge Breitenstein argued in dissent that a balance should be struck between the fifth amendment privilege and the policy requiring truthfulness by a witness-a balance which would permit impeachment use. In his view, Griffin was "not pertinent because in that case the defendant did not take the stand." Id. at 1069 (Breitenstein, J., dissenting).

${ }^{43} 498$ F.2d 1038 (D.C. Cir.), cert. granted sub nom. United States v. Hale, 95 S. Ct. 616 (1974) (No. 74-364). 
fendant's silence upon arrest in holding impermissible its use to impeach his trial testimony. Defendant Hale, arrested for robbery, took the stand at his trial and testified that he had obtained the money found in his possession at the time of his arrest by cashing his wife's welfare check. On cross-examination the prosecutor elicited that upon his arrest, Hale had declined to explain to a police interrogator, who asked the question directly, where the money had come from. Although the trial judge had issued a cautionary instruction, ${ }^{44}$ the court reversed Hale's conviction, concluding:

The premise underlying Harris is that if a defendant voluntarily gives statements to the police that contradict his trial testimony those statements are admissible because they are obviously relevant for assessing credibility. When, however, a defendant is informed that he has a right to remain silent, and then exercises that right, there is nothing inconsistent if he subsequently offers exculpatory testimony at trial. ${ }^{45}$

Thus, subsequent to Harris, courts of appeals in four circuits have decided the impeachment use of silence question. The facts of Ramirez, which permitted impeachment by proof of silence upon arrest, and those of Johnson and Anderson, which disallowed it, are indistinguishable. All involved silence after arrest, and use of that silence to impeach exculpatory testimony given at that trial. And Burt, on slightly different facts, had also permitted impeachment by prior silence. There was thus sharp conflict in the law when Agnellino came before the Third Circuit. That case presents the most extensive consideration to date of the respective interests involved in resolving the impeachment use of silence question. Thus, despite the sharp division among members of the panel, Agnellino is likely to have a significant influence upon the final resolution of this important constitutional question. For that reason, this Comment's analysis of impeachment use of post-arrest silence attempts to probe the soundness of the Agnellino resolution of the issue.

44 The dissenting opinion, while denying that the cross-examination regarding prior silence was impermissible, would have held that even if there had been error, the judge's cautionary instruction to the jury rendered it harmless beyond a reason: able doubt. Id. at 1053-54 (Wilkey, J., dissenting).

${ }^{45} I d$. at 1042 (opinion of the court). The court compared the facts in Anderson to those in Grunewald and concluded, contrary to the result Judge Hunter reached in Agnellino, see note 128 infra, that the circumstances of post-arrest silence, even more than those of silence before a grand jury, negate any inconsistency between the silence and subsequent exculpatory trial testimony. Id. at 1042-43. 


\section{Agnellino v. New Jersey: A Court Divided}

Attilio Agnellino owned and operated a restaurant which the police searched pursuant to a warrant issued by a local magistrate. They seized two rolls of stolen carpeting and three stolen air conditioners. Shortly following his arrest and the rendition of the Miranda warnings, the police questioned Agnellino regarding the goods found during the search. He replied that he had purchased the air conditioners for $\$ 100$ each and had obtained a "good buy" on the carpeting. ${ }^{46} \mathrm{He}$ was not asked and did not volunteer any further information concerning the circumstances surrounding his acquisition of the merchandise. At trial, he testified in detail about the circumstances of his purchases. ${ }^{47}$ In his closing argument to the jury, the prosecutor argued that if the testimony were true, "a normal human being" would have given a full explanation at the time of arrest. ${ }^{48}$ Agnellino's failure to do so raised, in the prosecutor's view, an inference of noncredibility. ${ }^{49}$ The trial judge overruled defendant's objection "that no defendant should be penalized for taking shelter in his constitutional right to remain silent" and ruled

${ }^{46}$ Agnellino v. New Jersey, 493 F.2d 714, 715 (3d Cir. 1974). A police officer testified that in reply to the question whether the air conditioners were "hot or stolen," appellant had stated "[f]or that price I wouldn't be surprised." Agnellino, though, denied having said this.

${ }^{47}$ Agnellino testified that he had purchased the carpeting from an unidentified interior decorator in Camden and the air conditioners from one Bill Gordon. Bill Gordon could not be located at the time of the trial, nor, apparently, could the interior decorator from Camden. Agnellino claimed to have had a receipt for the air conditioners but was unable to locate it following the police search of his premises. Brief for Appellant at 4-5, Agnellino v. New Jersey, 493 F.2d 714 (3d Cir. 1974).

48493 F.2d at 715 . The prosecutor's full comment was as follow's:

Now, you take Mr. Agnellino's story. And you consider the logic of the story. Start right off the bat the night of the raid, the police come, Lieutenant King and I forget the number, you may recall it, a number of police officers are on the scene. They go into this shed.

[S]ay this stuff was coming into your shed and you had three air conditioners and six rolls of rugs. And there's an indication they are looking for stolen property. Logically what would a normal human being do in that situation? I know what you would do and you know what I would do. I'd say wait a minute, let's find Bill Gordon, that's where I-got those air conditioners from, let's find the interior decorator in Camden.

Following an objection by defense counsel which was overruled, the prosecutor continued:

So I was saying in assessing Mr. Agnellino, I think you have a right to say that to yourself. Well, what would a normal human being do when the police are there? There's a raid going on and the property apparently has been stolen and it just doesn't ring true, this man if he didn't have some guilty knowledge wouldn't have done that. And that's what you're looking for in this case.

Id. at $715-16$.

4: Id. at 716 n.2. 
the prosecutor's argument to be "fair comment."50 Agnellino was convicted of receiving stolen property, and after exhausting state remedies ${ }^{51}$ sought habeas corpus relief. The district court denied the writ ${ }^{52}$ and Agnellino appealed to the Third Circuit, arguing that the prosecutor's comment upon his arrest silence violated the fifth amendment. ${ }^{53}$

Although the Third Circuit panel was unanimous in finding no fifth amendment violation, the three judges disagreed on nearly every material point leading to the affirmance. The initial disagreement was whether the case in fact raised the issue of impeachment by proof of defendant's assertion of the privilege. Judge Hunter, writing the principal opinion, viewed the prosecutor's comment as referring to Agnellino's failure to reveal to the police the source of the goods, which he saw as a conscious exercise of the privilege by Agnellino; ${ }^{54}$ in his view, the issue would be squarely raised. Chief Judge Seitz, concurring in the result, thought the comment had been directed at Agnellino's limited response to police questions-a prior statement, which differed from his trial testimony "both in the choice of words and in the details offered." 55 Judge Weis, also concurring in the result, referred to "variations between the tenor" of Agnellino's arrest "statement" and his trial testimony, ${ }^{56}$ and argued that by responding to police interrogation Agnellino had waived his right to remain silent. ${ }^{57}$ The concurring judges would thus

$50 I d$. at 716 .

5 The conviction was affirmed by the Appellate Division of the Superior Court of New Jersey in an unpublished opinion of September 29, 1971. Letter from Robert I. Ansell to the University of Pennsylvania Lau Review, Aug. 12, 1974. A petition for certification to the Supreme Court of New Jersey was denied, 59 N.J. 434, 283 A.2d 533 (1971), as was a subsequent petition for certiorari, 407 U.S. 909 (1972).

\$2 The writ was denied by the District Court for the District of New Jersey in an unpublished opinion of October 16, 1972. Letter from Robert I. Ansell to the University of Pennsyluania Law Review, Aug. 12, 1974.

53 Agnellino also claimed on appeal that the search warrant issued by a magistrate was not supported by facts sufficient to constitute probable cause. The panel was unanimous in rejecting this claim. $493 \mathrm{~F} .2 \mathrm{~d}$ at $725-28,729$.

54 Id. at $717-18$.

${ }^{55}$ Id. at 729 (Seitz, C.J., concurring). Judge Hunter convincingly demonstrated that even if the trial testimony were inconsistent with Agnellino's brief responses to police questions in the respects urged by Chief Judge Seitz, the prosecutor's comments would not have been justified: those comments did not refer to the inconsistencies discerned by Chief Judge Seitz, but to what Agnellino did not say upon his arrest. Id. at 717 \& nn.5-6 (opinion of the court).

${ }^{56} \mathrm{Id}$. at 730 (Weis, J., concurring).

${ }^{57}$ Id. Judge Weis' argument that by responding to initial questions Agnellino waived his right to remain silent is inconsistent with the pronouncement of Miranda 
have decided the case directly under the Harris prior inconsistent statement rationale, without reaching the issue of impeachment by proof of silence upon arrest.

Because Judge Hunter viewed the facts as raising the issue of impeachment use of post-arrest silence, Chief Judge Seitz was motivated to set forth his views upon the issue, although he did not consider it raised. ${ }^{58}$ Judge Hunter would have read Burt as resolving the question in favor of impeachment use of post-arrest silence under the Harris rationale, ${ }^{59}$ and would have rested his decision on Burt alone. Chief Judge Seitz, however, read Burt as allowing impeachment use of silence only when that silence was not "in face of accusation." ${ }^{\circ 0}$ Because of this disagreement over the scope of the Burt holding, Judge Hunter was moved to set forth a full exposition of his views upon the constitutional questions involved. His opinion is the most complete discussion to date of the impeachment use of silence upon arrest. Although his analysis is not immune from criticism on several points-and, it will be submitted, is wrong in one significant respect-it does represent an attempt to reconcile the conflicting penalty and impeachment doctrines upon a reasoned basis, which is a refreshing change from the characteristic failure of some of the previous approaches to the problem to treat material issues. ${ }^{61}$ The remainder of this Comment is devoted to a critical analysis of the approach taken by Judge Hunter in Agnellino. This will be accomplished by outlining his analysis of the penalty and impeachment issues and by relating to the analysis of those two issues the treatment they have received in other recent court of appeals cases, concluding in each instance with an evaluation of the Agnellino analysis and a suggested resolution of the issues.

that "where in-custody interrogation is involved, there is no room for the contention that the privilege is waived if the individual answers some questions or gives some information on his own prior to invoking his right to remain silent when interrogated." Miranda v. Arizona, 384 U.S. 436, 475-76 (1966) (footnote omitted).

s8 493 F.2d at 728-29 (Seitz. C.J., concurring).

:"Id. at 718-19 (opinion of the court); se' text accompanying notes 31-37 supra. 6o 493 F.2d at 728 (Seitz, C.J., concurring).

6) The Court in Ramirez did not address the question whether impeachment use of silence might not constitute an impermissible penalty under Griffin and prior Fifth Circuit cases. See text accompanying notes 14-16 supra. And the court in Johnson declined to consider whether impeachment use of silence, because of the difference in the nature of the penalty and because of the asserted state interest in getting truthful testimony, was distinguishable from Griffin and the cases prohibiting guilt use of silence upon arrest. See text accompanying notes 64-66 infra. 


\section{The Griffin "Penalty" Doctrine as a BARRIER TO IMPEACHMENT USE OF SilENCE UPON ARREST}

\section{A. Introduction: The Nature of the "Penalty"}

Before beginning the analysis of the treatment given the Griffin doctrine of penalizing the exercise of the fifth amendment privilege in Agnellino, it is necessary to explore the asserted distinction between the "penalty" which results from use of a defendant's silence to impeach his trial testimony and the "penalty" which flows from its use as evidence of guilt. The distinction is central to the Third Circuit's analysis and, under the most recent Supreme Court interpretation of the penalty doctrine, to any proposed resolution of the impeachment use question. Few courts, however, have been willing to grapple with the implications of the distinction.

In Johnson v. Patterson, ${ }^{62}$ the Tenth Circuit relied upon the holding of Griffin, and upon its logical extension in prior cases forbidding guilt use of post-arrest silence in the case of a nontestifying defendant, to disallow impeachment use of that silence against a defendant who does testify at his trial. The court dismissed the government's attempted distinction between the two different uses with only a brief statement: "This distinction is not well taken. A penalty is levied on the exercise of his constitutional right in any event, and the jury may as easily draw prejudicial inferences." ${ }^{3}$ This statement obviously glosses over the crucial questions whether all "penalties" are per se impermissible and whether, if not, there is a sufficient difference in the nature of the penalties involved in the two uses to justify different results. Courts which have been faced with the impeachment use question have not, as a general rule, given any serious attention to these questions. ${ }^{64}$

t2 475 F.2d 1066 (10th Cir.), cert. denied, 414 U.S. 878 (1973).

${ }^{63} \mathrm{Id}$. at 1068.

64 The exception is Fowle v. United States, 410 F.2d 48, 53-54 (9th Cir. 1969), where the court recognized that the "penalty" imposed by impeachment use of silence upon arrest differs from the "penalty" of guilt use enunciated in Griffin. The court concluded that the differences did not warrant a difference in result, however, and held the impeachment use unconstitutional as an impermissible penalty upon the exercise of the privilege. The Foule court, though, did not have the benefit of the subsequent Supreme Court cases refining the penalty doctrine upon which Judge Hunter relied in Agnellino to reach the contrary result. See text accompanying notes 67-71, 84-87 infra. In United States v. Anderson, 498 F.2d 1038 (D.C. Cir.), cert. granted sub nom. United States v. Hale, 95 S. Ct. 616 (1974) (No. 74-364), the most recent case to consider the issue, the court held impermissible impeachment use of silence 
It is important, however, to determine the precise nature of the penalty placed upon the exercise of the fifth amendment privilege by impeachment use of post-arrest silence, and to compare this penalty with that flowing from its use as substantive evidence of guilt. The penalty can be viewed from two perspectives. First, at the time the defendant is warned of his right to remain silent, the burden of impeachment use of silence is that the defendant must consider the possible effect of his silence upon the jury if, at a later trial, he should elect to take the stand. This burdens defendant's decision whether to assert the privilege. Second, if the defendant actually takes the stand to testify, the penalty is that the jury will learn of his prior assertion of the fifth amendment and will be urged to infer noncredibility of the "inconsistent" trial testimony. Cases which have permitted impeachment use of silence upon arrest tend to rely upon the former description of the penalty and to minimize its significance, ${ }^{65}$ while cases prohibiting the impeachment rely upon the latter description and note its prejudicial effect. ${ }^{66}$ It should be apparent, however, that the impeachment use penalty must

without considering the distinction between the nature of the penalties imposed by impeachment use and guilt use of silence. The penalty rationale, however, was not the principal ground of the opinion. See text accompanying notes 43-45 supra.

This tendency of the early cases to proscribe impeachment use as a discerned penalty without further inquiry into the nature of the penalty and the differences in justifications advanced for the different penalties is understandable in light of the broad language in which the penalty doctrine was articulated in Griffin and cases following closely thereafter. In holding, for example, that an attorney's disbarment, Spevack v. Klein, 385 U.S. 511 (1967), and a policeman's discharge, Garrity v. New Jersey, 385 U.S. 493 (1967), for having asserted the fifth amendment are impermissible penalities upon the exercise of the privilege, the Court defined the impermissible penalty as "the imposition of any sanction which makes assertion of the Fifth Amendment privilege "costly." Spevack v. Klein, supra at 515. In another line of cases, the Court held impermissible a statutory scheme permitting avoidance of the death penalty by a guilty plea waiving jury trial, United States v. Jackson, 390 U.S. 570 (1968), and a procedure permitting use at trial of a defendant's testimony at a pretrial hearing on a motion to suppress, Simmons v. United States, 390 U.S. 377 (1968). In the former case the Court defined the gravamen of the penalty as "not that it necessarily coerces guilty pleas and jury waivers but simply that it needlessly encourages them. A procedure need not be inherently coercive in order that it be held to impose an impermissible burden upon the assertion of a constitutional right." United States v. Jackson, supra at 583 . Under the early cases, virtually any practice which constituted a discernible burden would be held unconstitutional; further inquiry was unnecessary.

${ }_{65}^{65}$ Agnellino v. New Jersey, 493 F.2d 714, 723-25 (3d Cir. 1974); United States ex rel. Burt v. New Jersey, 475 F.2d 234, 239 (3d Cir.) (Rosenn, J., concurring), cert. denied, 414 U.S. 938 (1973).

${ }^{66}$ Johnson v. Patterson, 475 F.2d 1066, 1067-68 (10th Cir. 1973), cert. denied, 414 U.S. 878 (1973). 
be considered from both perspectives in evaluating its full impact upon the assertion of the privilege.

In contrast to the penalty involved in impeachment use, considered from both perspectives, is the penalty involved in the guilt use cases, which are more nearly analogous to Griffin. In these cases the "penalty" consists of urging guilt from the assertion of the privilege, which can be done whether the defendant testifies or not. The former case, by contrast, involved the analytically distinct and arguably lesser penalty of urging noncredibility of the defendant's testimony, a penalty which could be imposed only if the defendant decided to testify at the trial. These distinctions suggest that a more profound analysis than that provided by the Tenth Circuit is necessary before one may conclude that the same result should obtain in both cases.

\section{B. The Agnellino Interpretation of Griffin}

The principal opinion in Agnellino was written by Judge Hunter. He began his analysis of the fifth amendment penalty doctrine by recognizing that recent decisions of the Supreme Court have significantly refined and limited the broad language in which the doctrine was first articulated. He relied principally on McGautha v. Califormia" for the proposition that "not all 'burdens' or 'fetters' on a defendant's choice arise to the level of an unconstitutional penalty."68 In McGautha, the defendant Crampton argued that the Ohio procedure providing for a single trial at which both guilt and punishment were determined by a single jury was an impermissible penalty upon his privilege against self-incrimination, since he could not take the stand to testify in mitigation of punishment without incurring the risk of damaging his case on the issue of guilt. The Supreme Court indicated that it would consider a penalty impermissible only if

67402 U.S. 183 (1971).

68493 F.2d at 723. As early as United States v. Jackson, 390 U.S. 570 (1968), the Court had provided the basis for limiting the penalty doctrine by stating that the penalty there involved was impermissible because it "needlessly penaliz[ed]" the exercise of a constitutional right. Id. at 583. By implication, some procedures which penalize the exercise of a constitutional right, although not "needlessly," might be allowed to stand. It has been correctly argued that this was a test of "strict necessity" which would uphold a state procedure which penalized the assertion of a constitutional right only if that procedure were absolutely essential to the state's system of criminal justice. Chaffin v. Stynchcombe, 412 U.S. 17, $45-46$ (1973) (Marshall, J., dissenting). It is clear, however, that recent cases have adopted a far less stringent test. See text accompanying notes 81-87 infra. 
"compelling the election [between incurring the penalty and foregoing the right] impairs to an appreciable extent any of the policies behind the rights involved."69 After examining certain "penalties" which had never been thought impermissible, ${ }^{70}$ the Court concluded that "the policies of the privilege against compelled self-incrimination are not offended when a defendant in a capital case yields to the pressure to testify on the issue of punishment at the risk of damaging his case on guilt." ${ }^{\text {"1 }}$ The Court thereby indicated that the imposition per se of a burden or penalty does not render a practice unconstitutional; inquiry must be made into the effect of the asserted penalty upon the underlying rights involved.

In attempting to make this inquiry, Judge Hunter contrasted the penalty arising from impeachment use of a defendant's silence upon arrest with the penalty held impermissible in Brooks v. Tennessee. ${ }^{72}$ In Brooks, the Supreme Court reversed a conviction obtained under a Tennessee procedure which required a defendant who desired to testify to do so before any other testimony for the defense was heard. The "penalty" for failure to testify first was the prohibition against testifying later in the trial. Judge Hunter found significantly less impairment of the policies underlying the fifth amendment in Agnellino than in Brooks:

First, the "penalty" imposed on appellant was much less severe than that imposed by the Tennessee statute in Brooks. Instead of losing his right to testify at a future time, appellant was merely subjected to the "traditional truth-testing devices of the adversary process." Second, unlike Brooks, this lesser "penalty" was not a consequence of appellant's decision to remain silent; the penalty arose only because the defendant took the stand. ${ }^{73}$

69402 U.S. at 213.

70 The allowable "penalties" to which the Court referred are: (1) disallowing a defendant who takes the stand to assert the privilege against cross-examination reasonably related to the scope of direct examination; (2) permitting a defendant who takes the stand to be impeached by proof of prior convictions; (3) requiring a defendant whose motion for acquittal at the close of prosecution's evidence is denied to decide whether to stand on his motion or put on a defense, knowing that by putting on the defense he may provide additional support for a guilty verdict; and (4) requiring a defendant to give notice of his alibi defense to the state before trial upon pain of not being able to assert it at trial if he fails to give notice. Id. at 215-16.

${ }^{71} I d$, at 217.

72406 U.S. 605 (1972).

73493 F.2d at 724 (footnote omitted). Although the second argument relied upon by Judge Hunter is not, in itself, a satisfactory answer to the penalty argument, 
Thus, applying the policy impairment test of McGautha, Judge Hunter concluded that the nature of the penalty in the impeachment use case is sufficiently different from that involved in Griffin that permitting the practice would not seriously impair the policies underlying the fifth amendment.

Judge Hunter's analysis of the penalty doctrine as a barrier to impeaching the credibility of a defendant's trial testimony by proof of silence upon arrest involves two aspects not present in the earlier court of appeals cases. The first is his perception of the difference in the nature of the penalty involved in impeachment use of the post-arrest silence from that involved in guilt use. The second is his recognition that the penalty doctrine, as viewed by a Supreme Court less solicitous than it once was of the rights of the accused when balanced against legitimate societal interests, is not a barrier of absolute impenetrability. Although Judge Hunter felt impelled, because of these perceptions, to hold the impeachment use of post-arrest silence permissible, two basic lines of argument can be advanced to oppose his result. First, it can be argued that, even accepting the relaxation of the penalty doctrine implicit in the policy impairment test of McGautha, allowing impeachment use of silence upon arrest would, contrary to Judge Hunter's conclusion, impair the policies underlying the fifth amendment privilege. Second, it can be argued that the emphasis of the policy impairment test has been modified by a subsequent Supreme Court decision $^{74}$ which Judge Hunter failed to take into account and which should have led to a different result in Agnellino. It is difficult to see, however, how a convincing argument can be based upon the former line of reasoning.

In his concurring opinion in Agnellino, Chief Judge Seitz took issue with the first contention, arguing that impeachment use of post-arrest silence would impair the policies underlying the fifth amendment privilege against self-incrimination. He drew a contrast between the exclusionary rule of Miranda, which he found to admit of a logical exception for impeachment purposes, and the rationale prohibiting use of an assertion of the privilege to infer guilt, which, he argued, does not admit of such exception. He posited that under current analysis the fifth and four-

S'' note 36 supra, it is appropriate here, as it bears upon whether, under the McGautha penalty analysis, permitting impeachment use of silence upon arrest would impair the compulsion policies of the fifth amendment.

${ }^{74}$ Chaffin v. Stynchcombe, 412 U.S. 17 (1973). See text accompanying notes 84-88 infra. 
teenth amendments comprise three related prohibitions: First, involuntary statements of an accused are excluded for all purposes; second, silence cannot be urged to infer guilt; and third, if an accused makes a voluntary statement without knowledge of his rights, it is excluded from use as direct, but not as impeachment evidence. ${ }^{75}$ The third prohibition, he argued, is different "in type" from the first two. The Miranda rule is a "prophylactic measure" which, in its prohibition of direct use of a statement obtained without the required warnings, protects both innocent defendants who, in ignorance of their rights, make a statement which is subject to inculpatory construction, and guilty defendants who know what their rights are. Impeachment use of voluntary but unconstitutional statements is merely an exception to the prophylactic rule, Chief Judge Seitz argued, not to the fifth amendment itself, and is justified as a "deterrent to intentional dishonesty by defendants."

The protection against use of silence to infer guilt, like the protection against use of coerced statements, has not given rise to any prophylactic rule such as $\mathrm{Mi}$ randa lays down. To say that a defendant's silence in the face of accusation can be used to impeach his testimony would have the same effect as allowing impeachment use of coerced confessions. The law has recognized that no testimonial statement may be drawn from silence in the face of police accusation, nor from a statement made under duress, that is sufficiently reliable to be admitted for any purpose in a criminal trial. ${ }^{\mathbf{7 6}}$

This argument, however, is not persuasive. It attempts to resolve the conflict between Griffin and Harris by a legal nicety rather than by balancing the interests involved. Moreover, the legal nicety adopted for the purpose has a weak legal basis. No reason is given for equating use of arrest silence with use of an involuntary confession, and none is readily apparent. On the contrary, the rationale for the Griffin prohibition of an inference of guilt from silence corresponds more closely to the rationale of the Miranda exclusionary rule than to that of the cases prohibiting all use of involuntary confessions. ${ }^{77}$ The Griffin dissent pointed out that the Court's decision went beyond the tradi-

75493 F.2d at 728 (Seitz. C.J.. concurring).

${ }^{76} \mathrm{Id}$. at 729 (emphasis added).

${ }^{77}$ Sec, e.g., Haynes v. Wlashington, 373 U.S. 503 (1963); Chambers v. Florida, 309 U.S. 227 (1940); Bram v. United States, 168 U.S. 532 (1897). 
tional "compulsion" rationale of the involuntary confession cases, and commentators have elaborated upon that departure. $^{78}$ Indeed, in a subsequent case the Supreme Court characterized the basic purpose of the Griffin rule as being "to discourage courts from penalizing use of the privilege against self-incrimination."79 The rule against drawing an inference of guilt from a defendant's silence, like the prophylactic Miranda rule, is one step removed from the traditional concern of the fifth amendment that testimony not be compelled. And it must be admitted that impeachment use of post-arrest silence is yet another half-step removed from those concerns. Both rules thus serve policies ancillary to those underlying the fifth amendment itself. If, as Chief Judge Seitz concedes, the Miranda rule can be excepted for impeachment purposes without impairing the policies of the fifth amendment, so, likewise, can the Griffin rationale. ${ }^{80}$

A more satisfying basis upon which to resolve the GriffinHarris conflict is to examine the "policy impairment" test itself and the treatment it has received in later decisions. As articulated in $M c$ Gautha, that test holds that a procedure which imposes a discernible burden upon the exercise of fifth amendment rights will not be declared an impermissible penalty unless it "impairs to an appreciable extent any of the policies behind the rights involved." 81 This formulation of the penalty doctrine has been criticized as not requiring the state to show a strong interest in the procedure which constitutes the burden ${ }^{82}$ and as permitting the Court to base its result on "dubious determinations of policy impairment." 83 The recent decision in Chaffin $v$. Stynchcombe ${ }^{84}$ indicates that although the Court is not willing to return to the broad language of the early penalty cases, which would invalidate per se all procedures which impose a perceptible burden upon the exercise of a constitutional right, it will require some

${ }^{78}$ See authorities cited note 14 supra.

${ }^{79}$ Johnson v. New Jersey, 384 U.S. 719, 727 (1966).

${ }^{80} \mathrm{~A}$ recent decision clearly indicates that a majority of the Court is now inclined to return to the traditional compulsion analysis in approaching the fifth amendment claims and to view departures from, for example, the Miranda rule, as something less than constitutional violations. Michigan v. Tucker, 417 U.S. 433, 439-46 (1974). The Court's reasoning in that case, indeed its very language, could as well be directed against the Griffin doctrine, especially as it is sought to be extended to bar impeachment use of arrest silence.

${ }^{81}$ McGautha v. California, 402 U.S. 183, 213 (1971).

82 See note 68 supra.

${ }^{83}$ The Supreme Court, 1970 Term, 85 HARv. L. Rev. 3, 291 (1971).

84412 U.S. 17 (1973). 
showing of a legitimate state interest in the procedure before declaring it a permissible burden.

In Chaffin, the Court was presented with a state practice which created the possibility that a jury retrying a defendant after his successful appeal or collateral attack upon a conviction could impose a harsher sentence than had the original jury. The Court held that this possibility did not impermissibly burden a defendant's right to challenge his conviction. ${ }^{85}$ The Court declared that if a state has a legitimate interest in a procedure, it will not be struck down merely because an "incidental consequence" of the procedure is that it burdens, to a less than substantial extent, the exercise of a constitutional right. ${ }^{86}$ If, however, "the only objective of a state practice is to discourage the assertion of constitutional rights it is 'patently unconstitutional.'

Although this articulation drew a strong dissent, ${ }^{88}$ it does seem to place at least some limitation upon the broad policy impairment test enunciated in McGautha and upon which Judge Hunter relied in Agnellino. Judge Hunter did not discuss the Chaffin limitation in his penalty analysis; yet it obviously weakens the persuasiveness of that analysis. He argued that impeachment use of post-arrest silence, although constituting a "penalty" upon the exercise of the privilege, does not significantly impair the traditional compulsion concerns of the fifth amendment. But Chaffin requires more. No penalty should be tolerated without a demonstration that the "penalty" is justified by a legitimate state interest which is materially advanced by the imposition of the burden. The analysis in the following section of the Comment will demonstrate that as an evidentiary matter, the asserted state interest in truthfulness is not materially advanced by permitting impeachment use of post-arrest silence. That being so, the penalty should be declared impermissible under the Chaffin formulation of the penalty doctrine.

${ }^{85}$ In developing its penalty analysis, the Court relied freely upon cases in which the penalty was upon the exercise of fourth, fifth, and sixth amendment rights. Thus, the fact that Chaffin dealt with a penalty upon the right to appeal does not mean that the penalty analysis enunciated therein has no application beyond the limited scope of the right to appeal.

${ }^{86} 412$ U.S. at 32 \& n.20.

${ }^{87}$ Id. (citation omitted).

${ }^{88}$ Justice Marshall, joined in his reasoning by Justices Douglas and Stewart. who each wrote a separate dissent, argued that cases subsequent to Jackson had not changed the penalty standard and that "[t]he question is still whether the burden on the exercise of the right . . . is necessary, not whether it is only incidental to the accomplishment of some legitimate state purpose." Id. at 44 (Marshall, J., dissenting). Finding no "necessity" in the rule permitting a jury to impose a harsher sentence on retrial, Justice Marshall would have reversed Chaffin's conviction. 


\section{The HaRris Impeachment Rationale as a Basis For IMPEACHMENT by Silence UPON ARREST}

\section{A. The Basis of the Harris Rationale}

The analysis in the previous section revealed that the doctrine of penalizing the exercise of a constitutional right, which has been advanced to oppose impeachment use of post-arrest silence, has now been cast in a form which would arguably permit that use if the procedure serves a legitimate state interest, despite an incidental burden on the exercise of the right to remain silent. ${ }^{89}$ Accordingly, the focus of the inquiry shifts to whether the opportunity to impeach testimonial evidence is such a legitimate state interest and, if so, whether use of post-arrest silence to impeach would materially advance that interest.

The first question does not require extended discussion. The right to impeach the testimony of an opponent's witness is considered fundamental to our adversary system of justice. The necessity for the impeachment right inheres in the nature of testimonial proof ${ }^{90}$ and provides much of the justification for the venerable common law institution of cross-examination. ${ }^{91}$ A vast body of law has developed defining the scope of the impeachment right ${ }^{92}$ and the means which may properly be used to impeach. ${ }^{93}$ It is clear that the right to impeach extends to a criminal defendant who chooses to take the stand.94 And the impeachment right. has been recognized in several contexts even when countervailing constitutional issues were raised. Thus, despite the possible prejudice to a defendant's fair trial, his prior valid convictions may be shown to impeach his credibility, ${ }^{95}$ and statements obtained in violation of Miranda, as well as evidence

${ }^{89}$ See text accompanying notes 67-69, 84-87 supra.

${ }^{40}$ When a witness testifies at trial, his assertion that fact $X$ exists is the only evidential fact before the trier. The trier is asked to infer from the witness' assertion that fact $\mathrm{X}$ does, indeed, exist. The process of impeachment permits an opponent to question the cogency of this inference by attempting to explain away the evidential fact of the witness' assertion by an hypothesis other than the existence of fact X. See 3A J. Wigmore, Evidence $\S 22$, at 636-41 (Chadbourne rev. 1970).

${ }^{91}$ See C. MсCormick, supra note 14 , § 22 , at 49.

${ }^{92}$ See $3 \mathrm{~A}$ J. WIGMORE, supra note $90, \S \S 884-918$.

${ }^{93}$ See id. $\$ \$ 920-1046$, at 723-1065.

${ }^{94}$ See id. $\$ \$ 890-91$, at $654-57$.

95 Spencer v. Texas, 385 U.S. 554, 560-62 (1967); of. Loper v. Beto, 405 U.S. 473 (1972) (plurality holding impeachment by a prior conviction obtained in contravention of a defendant's right to counsel violative of due process; Justice White, concurring in the result, would only have the court of appeals determine certain issues on remand to elucidate whether there was harmless error). 
obtained in violation of the fourth amendment, may be used to impeach. ${ }^{96}$ These precedents in the constitutional area, coupled with the deeply rooted tradition favoring the opportunity to impeach testimonial evidence, suggest that the Court might not hestitate to find, in a clash between the impeachment right and the recent articulation of the penalty doctrine, that impeachment of a defendant's testimony-the interest of the judicial system in getting at "truth"-is a legitimate state interest which, if subserved by use of post-arrest silence to impeach, will prevail over the incidental "penalty" which may result. The asserted interest here is clearly stronger than the state's interest in permitting a jury to impose a harsher sentence upon retrial following reversal, which was held to justify the burden upon the right to appeal in Chaffin. ${ }^{97}$

The second question, whether impeachment use of postarrest silence would materially advance this legitimate interest in testing the truthfulness and accuracy of a defendant's testimony, is much more problematical and has been the principal point upon which the courts of appeals have disagreed in the impeachment use cases. Here the inquiry must begin with Harris, for it is the basis for the Third and Fifth Circuits' holdings permitting impeachment use. The impeachment exception to the Miranda exclusionary rule articulated by the Supreme Court in Harris is based upon the longstanding principle of the law of evidence that a witness may be impeached by the showing of a prior inconsistent statement. ${ }^{98}$ The key word here is obviously "inconsistent," for if the prior statement is not inconsistent with the trial testimony, the theoretical basis for its impeachment use vanishes. In Harris, the Court acknowledged that the defendant's prior statement "contrasted sharply" with his trial testimony, and thus "undoubtedly provided valuable aid to the jury in assessing [his] credibility . . . ."99 Although the Harris rationale cannot be applied to statements which are not inconsistent with the defendant's trial testimony, ${ }^{100}$ the courts have

${ }^{96}$ Harris v. New York, 401 U.S. 222 (1971); Walder v. United States, 347 U.S. 62 (1954); see text accompanying notes 17-25 supra. See also Comment, The Impeachment Exception to the Constitutional Exclusionary Rules, 73 Colvm. L. Rev. 1476 (1973); 34 U. CHI. L. Rev. 939 (1967).

${ }^{17}$ See Chaffin v. Stynchcombe, 412 U.S. 17, 45-46 (1973) (Marshall, J., dissenting).

98 3A J. WIGMORE, supra note 90, §§ 1017-46.

99 Harris v. New York, 401 U.S. 222, 225 (1971).

${ }^{100} \mathrm{Cf}$. United States $x x$ rel. Wright v. La Vallee, 471 F.2d 123, 127 (2d Cir. 1972), cert. denied, 414 U.S. 867 (1973). 
not defined the degree of inconsistency required to render impeachment use of the prior statement permissible. ${ }^{101}$

When the problem changes from determining the inconsistency of two statements to determining the inconsistency of trial testimony with prior silence, however, the difficulties are multiplied. Rather than explain why silence upon arrest is or is not inconsistent with testimony at trial, courts on both sides of the issue have simply asserted a position, virtually a priori, based on the facts of the particular case. For example, the Fifth Circuit just assumed Ramirez's silence upon arrest was a "prior inconsistent act."102 Two of the three judges sitting on the Third Circuit panel in Burt merely asserted that the defendant's silence was "inconsistent with his testimony at trial that the shooting was accidental."103 Nor did the Tenth Circuit, in disallowing impeachment use of silence, shed any light upon the problem of determining inconsistency; it noted only that "[t]he premise of Ramirez is that silence at [the] time of arrest is an act inconsistent with the testimony given at trial. We simply deny the validity of the premise." 104 The only in-depth discussion of the problem of the inconsistency of arrest silence with later testimony at trial, and hence of the probative value of that silence upon the issue of credibility, is in Judge Hunter's Agnellino opinion. And it is submitted that his analysis of this aspect of the question is not compelling.

\section{B. The Application of the Impeachment \\ Rationale in Agnellino}

In approaching the question of the legitimacy of using a defendant's post-arrest silence to impeach his testimonial credibility at trial, Judge Hunter relied upon two Supreme Court decisions which dealt with a similar problem in different contexts. In Raffel $v$. United States, ${ }^{105}$ the Court allowed cross-examination of the defendant which disclosed that on a previous trial for the same offense, he had not taken the stand to deny testi-

${ }^{101} \mathrm{Cf}$. 3A J. WIGMORE, supra note $90, \S 1040$, at 1048-52 (setting forth varying standards defining the degree of inconsistency required at common law to permit impeachment of a witness by prior statement).

102 United States v. Ramirez, 441 F.2d 950, 954 (5ूth Cir.), cert. denied, 404 U.S. 869 (1971).

${ }^{103}$ United States $e x$ rel. Burt v. New Jersey, 475 F.2d 234, 238 (3d Cir.) (Rosenn, J. concurring), cert. denied, 414 U.S. 938 (1973).

${ }^{104}$ Johnson v. Patterson. 475 F.2d 1066, 1068 n.3 (10th Cir.) (citation omitted), cert. denied, 414 U.S. 878 (1973).

10.527 I U.S. 494 (1926). 
mony similar to that which he had denied at the instant trial. Because of the posture of the case, however, the question of the probative value of the prior silence upon Raffel's credibility at the second trial was not resolved. ${ }^{106}$ Some thirty years later, the Court decided Grunewald $v$. United States. ${ }^{107}$ The defendant Halperin had previously been called before a federal grand jury investigating corruption in the Bureau of Internal Revenue; there he asserted the fifth amendment in response to questions concerning his relationship with Grunewald. At trial, he responded to similar questions in a manner consistent with his innocence, and the trial court allowed the prosecutor to bring out on cross-examination that when testifying before the grand jury, he had asserted his privilege in response to the same questions. Although reversing, the-Court expressly declined to overrule Raffel. ${ }^{108}$ Instead, it merely declared that Raffel had not established as a matter of law that prior silence "is always to be deemed to be a prior inconsistent statement, irrespective of the circumstances under which the claim of privilege was made."109 Exercising its supervisory power over the federal courts, the Supreme Court required that before impeachment use can be made of a prior assertion of the privilege, the trial court must satisfy itself by an examination of the circumstances that an inconsistency in fact exists. After a detailed examination of the particular circumstances before the grand jury, ${ }^{10}$ the Court

${ }^{106}$ Raffel came to the Court as a certified question from the Circuit Court of Appeals for the Sixth Circuit. The question certified was: "Was it error to require the defendant, Raffel, offering himself as a witness upon the second trial, to disclose that he had not testified as a witness in his own behalf upon the first trial." Id. at 496. The Court in Grunewald v. United States, 353 U.S. 391 (1957), said that the Raffel Court had not focused on the probative value of the silence because the question as it came to the Court had been "in quite an abstract form." Id. at 420 .

107353 U.S. 391 (1957).

${ }^{108}$ Id. at 419-21. Justice Black, concurring, joined by Chief Justice Warren and Justices Brennan and Douglas, argued that Raffel should be explicitly overruled. Id. at 426-27 (Black, J., concurring).

${ }^{109}$ Id. at $419-20$.

110 The circumstances of the case which the Court relied upon in holding that no inconsistency sufficient to permit impeachment use of Halperin's assertion of the privilege existed were: (1) the charge of conspiracy, which by its nature increases the dangers of unwitting self-incrimination; (2) defendant's insistence before the grand jury that he was innocent and was asserting the privilege only on advice of counsel; (3) the nature of a grand jury proceeding, where defendant was compelled by subpoena to testify and did not have the right to counsel or other procedural safeguards available in an open court proceeding; and (4) defendant's knowledge that he was about to be indicted and his desire to refuse to help create a case against himself. These factors, the Court held, rendered defendant's silence before the grand jury "wholly consistent" with his trial testimony. Id. at 421-24. 
held that there was not such an inconsistency between his silence and his later testimony as to allow impeachment of the testimony by proof of the prior silence.

Relying upon the Court's apparent sanctioning of impeachment use of an assertion of the privilege in Raffel and upon its failure to rest Grunewald upon the fifth amendment, Judge Hunter concluded that "the Court impliedly recognized that evidence of silence is subject to ambiguous inferences which may diminish its reliability, yet only where one's prior silence is quite clearly consistent with innocence, and thus void of any probative value, [does] this evidentiary question [arise] to constitutional [due process] dimensions." 111 Comparing the facts of Agnellino's silence with those in Grunewald, where Halperin knew he was about to be indicted and was before a grand jury where he did not have the right to counsel, Judge Hunter concluded that the particular circumstances which made Halperin's silence not inconsistent with his trial testimony were lacking in Agnellino. Viewing Agnellino's silence upon arrest as inconsistent with his testimony at trial, Judge Hunter concluded that due process was not denied by permitting use of the silence to impeach that testimony. He read Harris as "consistent with and supportive of Raffel and Grunewald,"112 and found that the prior silence, because of its inconsistency with the trial testimony, met the Harris requirement that the "trustworthiness" of the impeaching evidence " 'satisf[y] legal standards.' "113

Judge Hunter's analysis of the penalty doctrine's applicability to impeachment by post-arrest silence decidedly reflects the current trend in Supreme Court analysis of that doctrine, and thus raises significant questions which courts did not deal with adequately in the previous cases involving impeachment use of silence. But the reasoning which led him to conclude that silence is probative of credibility, and should therefore be permitted, is highly questionable. A close examination discloses that even as a matter of sound impeachment theory, use of silence to impeach trial testimony does not advance the asserted state interest in arriving at "truth." The Chaffin test is therefore not met, and the burden on the defendant's right to remain silent is an impermissible one. Judge Hunter's legal analysis of the strict impeachment aspect of the issue resolves itself into two

11493 F.2d at 720 (footnote omitted).

$112 \mathrm{Id}$. at 721 .

${ }^{113}$ Id. (quoting 401 U.S. at 224). 
propositions: First, that one's assertion of the fifth amendment upon arrest can be probative of the credibility of trial testimony; and second, that the determination whether silence has probative value must be made on a case-by-case basis. ${ }^{114}$ These propositions must be scrutinized to determine whether they are in fact established by the authorities upon which Judge Hunter relied, and whether they constitute a sound and defensible resolution of the impeachment use question.

For these propositions Judge Hunter relied upon Raffel $v$. United States, ${ }^{115}$ which permitted cross-examination regarding a prior assertion of the privilege, and upon Grunewald $v$. United States, ${ }^{116}$ where the Supreme Court refused to hold that silence can never have probative value, basing its disallowance of the impeachment upon the failure of the particular circumstances of the case to show any inconsistency between the trial testimony and the prior silence. ${ }^{17}$ It is doubtful, however, whether Raffel and Grunewald should be read to have held that silence can be of sufficient probative value to permit its use to impeach. In Grunewald the Court specifically acknowledged that "[t]he Court, in Raffel, did not focus on the question whether the cross-

${ }^{114}$ Having concluded that use of post-arrest silence to impeach does not constitute an impermissible penalty upon the exercise of the right to remain silent, see text accompanying notes 72-73 supra, Judge Hunter also held that the probative value of an assertion of the right to remain silent is simply an evidentiary question not assuming constitutional proportions unless, under the particular circumstances, the silence is so void of probative value that its use would violate due process. Text accompanying note 111 supra. In so holding he relied upon Raffel, which permitted crossexamination regarding a prior assertion of the privilege, and upon the Court's having rested its Grunewald decision, which disallowed cross-examination regarding a prior assertion of the privilege, upon its supervisory power rather than upon the fifth amendment. Although both Raffel and Grunewald were decided prior to the Court's adoption of the penalty doctrine as an adjunct to the fifth amendment, the Grunewald majority recognized that its decision had "grave constitutional overtones." 353 U.S. at 423 . As subsequent penalty analysis has developed, the question whether post-arrest silence is probative of credibility will determine whether impeachment use of that silence is a permissible penalty; for if it is not probative, then no legitimate state interest is served by allowing its use as impeaching evidence, and its use would be an impermissible penalty under the Chaffin formulation. Thus, Judge Hunter's failure to discuss the Chaffin limitation, which tainted his conclusion on the penalty issue, see text accompanying note 88 supra, also renders suspect his conclusion that impeachment use of post-arrest silence is not a constitutional question unless the silence in a given case is so void of probative value as to violate due process. The probative value determination is an integral part of the determination whether a constitutionally impermissible penalty has been imposed.

115271 U.S. 494 (1926).

116353 U.S. 391 (1957).

117 Substantially the same use of Raffel and Grunewald was made by Judge Breitenstein in Johnson v. Patterson, 475 F.2d 1066 (10th Cir.) (Breitenstein, J., dissenting), cert. denied, 414 U.S. 878 (1973). 
examination involved was in fact probative in impeaching the defendant's credibility." 18 And the Grunewald holding itself was that Halperin's assertion of the fifth amendment before the grand jury was not sufficiently inconsistent with his testimony at trial to permit its impeachment use. Moreover, four members of the Court would have broadened the holding:

I agree with the Court that use of this claim of constitutional privilege to reflect upon Halprin's credibility was error, but I do not, like the Court, rest my conclusion on the special circumstances of this case. I can think of no special circumstances that would justify use of a constitutional privilege to discredit or convict a person who asserts it. ${ }^{119}$

Thus, to say that the Court has held that the assertion of the privilege can be probative of credibility is to stretch substantially what the cases have held. The only support to be found for this proposition is by negative implication from the approach taken by the Court in Grunewald-impeachment use of an assertion of the privilege is impermissible under these circumstances, so there are other circumstances under which it would be permissible. This is by no means a necessary inference.

Precedential support is thus lacking for the proposition that assertion of the privilege can be probative of credibility. The question must therefore be dealt with on its own merits. If use of an assertion of the fifth amendment is to be justified upon the impeachment rationale, consideration must be given not only to the probative value of that silence but also to other policies which form an integral part of impeachment theory and which may supervene to exclude from impeachment use even evidence otherwise probative of credibility.

If one were to concede that silence upon arrest can in some circumstances be probative of the credibility of a defendant's trial testimony, the approach requiring a case-by-case determination of inconsistency would have a surface logical appeal. ${ }^{120}$ Such an approach would be clearly preferable to a rule which would permit impeachment use of silence in all cases without

118353 U.S. at 420.

${ }^{119}$ Id. at 425 (Black, J., concurring).

${ }^{120}$ It has been noted, in the context of the inconsistency of a prior statement with testimony at trial, that "[i]n most rulings, the circumstances of the cases are individual, and they have no value as precedents." $3 \mathrm{~A}$ J. WIGMORE, supra note $90, \S 1040$, at 1049. The same would hold true in the silence situation, if its use to impeach is sanctioned at all. 
an inquiry into inconsistency under the particular circumstances of the case. ${ }^{121}$ The inference of inconsistency between trial testimony and prior silence may, indeed, be stronger in some circumstances than in others. ${ }^{122}$ But the underlying question is whether silence is ever, even in the cases in which the inference is arguably stronger, sufficiently probative of credibility that its use should be permitted.

In answering this question, one must look to the theoretical basis for impeachment of this type. Impeachment by showing a prior inconsistent statement, which is the type approved in Harris and the type sought to be extended to silence upon arrest, is essentially an empirical process. A prior statement inconsistent with one aspect of a witness' trial testimony is shown, and the trier of fact is asked to infer from this specific error that the witness' other assertions may also be erroneous. Casting the proposed course of empirical impeachment in deductive form ${ }^{123}$ highlights its lack of probative value. The syllogism would be:

When arrested for a crime, a person who truly has an alibi or defense will protest his innocence and assert the alibi or defense.

This defendant did not, upon arrest, assert the alibi or defense to which he is now testifying.

Therefore, this defendant's testimony in support of that alibi or defense is untrue.

As a general principle describing human behavior, the validity of the major premise is open to serious question. The fear, hos-

121 The Fifth Circuit, in a case following Ramirez, has apparently adopted such an approach. In United States v. Quintana-Gomez, 488 F.2d 1246 (Jth Cir. 1974), the court held an impeachment use of silence claim "to be foreclosed by" Ramirez despite circumstances arguably negating any inconsistency between trial testimony and post-arrest silence: None of the arresting officers spoke Spanish, and apparently, the defendant did not speak English. Id. at 1248.

${ }^{122}$ In Agnellino, for example, the defendant made certain statements but remained silent as to the details to which he testified at trial. These circumstances, it could be argued, permit a more certain inference of inconsistency and hence of probative value, than the facts of Ramirez or Johnson. A similar argument can be made on the Burt facts in that the defendant there remained silent concerning an occurrence other than that for which he was arrested. This would give rise to an inference of inconsistency undiminished by the possible alternative explanation that the defendant was asserting his privilege in response to police accusation. See Agnellino v. New Jersey, 493 F.2d 714, 728-29 (Seitz, C.J., concurring).

${ }^{123}$ Professor Wigmore suggested the use of the deductive form to assess the force of a proposed course of empirical impeachment. 3A J. Wicmore, supra note 90. $\S 874$, at $638-40$. 
tility, and disorientation attendant upon an arrest may well lead an accused not to cooperate. But more than this, in every case the defendant is told, when arrested, that he has a right to remain silent and that anything he says can and will be used against him in court. Through the warning delivered by the police officer, the state has placed its weight in favor of the defendant's remaining silent. His silence can always be explained as an exercise of the privilege. The availability of this alternate explanation, coupled with the state's assurance to the defendant that he may do so, completely strips the major premise of any validity as a general principle upon which to base impeachment use of post-arrest silence. For if there is an explanation for the asserted inconsistency other than that the trial testimony is untrue, which is the inference the prosecutor urges, the probative value of the silence upon the issue of credibility disappears, and its use to impeach cannot be justified.

Apart from the probative value of evidence sought to be used for impeachment purposes, the law has traditionally recognized auxiliary policies which may require exclusion of evidence from impeachment use even though it would be probative of credibility. Thus, in the case of prior inconsistent statements used to impeach, the auxiliary policies of avoiding confusion of issues and unfair surprise have resulted in the exclusion of impeachment evidence on matters collateral to the main issues of the trial ${ }^{124}$ and required that a witness be asked in advance whether he made the prior statement before the self-contradiction can be proved. ${ }^{125}$ Also, the general principle excluding evidence whose probative value is outweighed by potential prejudice to the party against whom it is offered applies not only to evidence offered for substantive purposes, but also to that offered for impeachment. ${ }^{126}$

Two considerations of auxiliary policy, in addition to the lack of probative value of the silence, require the exclusion of post-arrest silence as impeaching evidence. The first is the unavoidable difficulty of determining whether prior silence in a particular case is inconsistent with trial testimony. When there is a prior statement, a standard of inconsistency can be developed and applied against that statement. In the case of prior silence, however, there is nothing specific against which to apply the

${ }^{124} I d . \S \S 1020-23$.

${ }^{125}$ Id. $\$ \S 1025-39$.

${ }^{126}$ FED. R. Evid. 403; C. MCCormick, supra note 14, § 185, at 438-39. 
standard-only silence. This dilemma is doubtless responsible for the lack of a convincing demonstration in either Ramirez or Burt of how the silence was inconsistent with the trial testimony. ${ }^{127}$ Indeed, in Agnellino, Judge Hunter did not attempt to demonstrate how Agnellino's silence upon arrest was inconsistent with his trial testimony. He merely rested his determination of probative value upon the fact that the circumstances of Grunewald, where the Court held silence to have no probative value, were different in several respects from the circumstances of Agnellino. ${ }^{128}$

Moreover, adoption of the case-by-case approach suggested by Judge Hunter would permit trial courts to use varying standards in making the inconsistency determination. The possible variation in standards is significant, ranging from the view of one court that silence upon arrest is inconsistent only with a defendant's assertion that he did make a statement upon arrest, ${ }^{129}$ to the view of another court that anything said at trial is "inconsistent" with prior silence. ${ }^{130}$ One standard might require that the judge make an initial determination that the offered silence is necessarily inconsistent with the trial testimony before allowing the prosecutor to use it for impeachment purposes, while another would permit the judge to allow impeachment if a jury could reasonably infer inconsistency between the prior silence and the trial testimony. ${ }^{131}$ Similarly, the degree of inconsistency deemed necessary to permit impeachment use could

\footnotetext{
${ }^{127}$ See text accompanying notes 102-03 supra.

${ }^{128}$ The differences Judge Hunter perceived are these:

Appellant was not denied assistance of counsel; indeed he chose not to seek counsel. Nor were the appellant's replies restricted by the scope of the questions asked; he was free to fully explain answers which initially might have appeared superficially incriminating. Lastly, I do not think that appellant's statements at trial-if in fact made by appellant at the time of arrest-could have been erroneously construed by the police as inculpating appellant. Thus, I do not believe we are faced with a Grunewald-type situation.
}

493 F.2d at 721; $f$. notes 45.110 supra.

12:! People v. Bobo, 390 Mich. 355, 359, 212 N.W.2d 190, 192 (1973).

${ }^{130}$ This is how the Tenth Circuit. in a case following Johnson, characterized the rule approved in Ramirez. Deats v. Rodriguez. 477 F.2d 1023. 1024 (10th Cir. 1973). A subsecjuent case in the Fifth Circuit indicates that that court actually may have taken a position as broad as the interpretation sarcastically placed upon its Ramirez decision by the Tenth Circuit in Diats. United States v. Quintana-Gomez, 488 F.2d 1246 (5th Cir. 1974); ser note 121 supra.

131 Judge Vilkey, dissenting in United States v. Anderson, 498 F.2d 1038. 1046 (D.C. Cir.), cert. granted sub nom. United States v. Hale. 9j S. Ct. 616 (1974) (No. 74-364), while favoring impeachment use of post-arrest silence. conceded that before it can logically be used to impeach trial testimony. the silence must be "inconsistent" with that testimony. He would apparently admit proof of post-arrest silence as impeaching evidence if it is "arguably inconsistent with an innocent explanation." Id. at 1052 (Wilkey, J., dissenting). 
vary from the requirement of a "direct contradiction" to that of only a "material variance" between the silence and the testimony. ${ }^{132}$ Thus, the difficulty of making the determination of inconsistency in the case of post-arrest silence, when compared with the alternate explanation available in every case and the necessarily minimal probative value, strongly suggests adoption of a per se rule prohibiting impeachment use of silence upon arrest.

The second consideration of auxiliary policy arising from use of silence upon arrest to impeach trial testimony is the degree of potential prejudice to the defendant resulting from that practice. The danger always exists, in any case in which evidence is admissible only upon a single issue, that a jury will not restrict its consideration of the evidence to the narrow issue to which it is legally relevant. ${ }^{133}$ The law has attempted to deal with this danger through devices such as giving special instructions to the jury. This concern about impermissible use of evidence of limited admissibility underlay the restriction established in the Walder articulation of the impeachment exception to the exclusionary rule-that unconstitutionally obtained evidence can be used to impeach only as to collateral matters. ${ }^{134}$ For as the unconstitutionally obtained evidence is used to impeach a defendant on matters more central to the crime charged, the danger that the jury will consider the evidence in assessing guilt increases. Although the Court in Harris considered this distinction unimportant under the circumstances of that case, ${ }^{135}$ it becomes crucial when post-arrest silence is used to impeach trial testomony. This is so because the cases have uniformly held that use of silence upon arrest as substantive evidence of guilt violates the fifth amendment ${ }^{136}$ - a result mandated by the holding in Griffin. The testimony which the cases have allowed to be impeached by use of post-arrest silence, typically an alibi or a complete defense, is central to the guilt issue. When the jury is urged to infer noncredibility of a defendant's exculpatory

${ }^{132}$ These varying standards are employed in different jurisdictions for determining the degree of inconsistency necessary between trial testimony and a prior statement to permit its impeachment use. C. MCCORMick. supra note 14. \$ 34. at 68-69.

${ }^{133}$ Id. \$ 59, at 135-37; $1 \mathrm{~J}$. WigMore, EvideNCE $\$ 13$, at 299-303 (3d ed. 1940); U. Kan. L. Rev. 360, 367 (1972). See also H. Kalven \& H. Zeisel, The American Jury $127-28,177-80$ (1966).

134 Walder v. United States. 347 U.S. 62, 65-66 (1954). Se' also 34 U. CHI. L. Rev. 939. $941-44$ (1967).

13" Harris v. New York, 401 U.S. 222, 205 (1971).

${ }^{136} S^{\prime \prime}$ cases cited note 16 supra. 
testimony as a whole, because of his prior silence, the danger is far greater than in the case of impeachment by a prior statement that the silence, offered and legally admissible only on the issue of credibility, will be put to the unconstitutional use by the jury. ${ }^{137}$

The protection offered by the law of evidence against inappropriate impeachment and resulting prejudice, other than cautionary instructions to the jury, is the right of the party whose witness is impeached by proof of a prior inconsistent statement to explain away the inconsistency to the jury. ${ }^{138}$ There has been some suggestion in the impeachment use cases that this right would give the defendant adequate protection against possible guilt use of the impeaching silence. ${ }^{139}$ It seems anomalous, however, to argue that impeachment use of silence should be allowed and that defendants should be remitted to explaining their silence as an assertion of the fifth amendment, when this explanation would be available in every case. And it is not clear, given the inferences which laymen draw from an assertion of the privilege, ${ }^{140}$ that this would adequately ensure against a jury's misapplication to the forbidden issue of guilt, to the defendant's prejudice, of his silence offered and admissible only for impeachment purposes.

\section{Conclusion}

The question whether the government should be allowed to prove a criminal defendant's post-arrest silence in an attempt to impeach his exculpatory trial testimony must be resolved by a

${ }^{137}$ In IValder, the Court said:

Of course. the Constitution guarantees a defendant the fullest opportunity to meet the accusation against him. He must be free to deny all the elements of the case against him without thereby giving leave to the Government to introduce by way of rebuttal evidence illegally secured by it, and therefore not available for its case in chief.

347 U.S. at 65 . The Court in Harris, it is true, permitted impeachment by a prior statement which went directly to the crime charged. Permitting use of a prior statement which was inconsistent with one aspect of Harris' trial testimony is quite different from permitting impeachment use of prior silence, which, because of its ambiguous nature. can be considered by a jury as inconsistent with the defendant's entire trial testimony.

${ }^{138} 3 \mathrm{~A} \mathrm{~J}$. Wigmore, supra note $90, \S \S 1044-46$, at 1062-65.

13:" E.g., United States ex rel. Burt v. New Jersey, 475 F.2d 234, 238 (3d Cir.) (Rosenn, J.. concurring). cert. denied, 414 U.S. 938 (1973).

${ }^{140}$ In Uilmann v. United States, 350 U.S. 422, 426-27 (1956), Justice Frankfurter noted: "Too many, even those who should be better advised, view this privilege as a shelter for wrongdoers. They too readily assume that those who invoke it are either guilty of crime or commit perjury in claiming the privilege." 
dual analysis. First, the impact of such a practice upon the constitutional rights of the accused, under presently accepted doctrines, must be assessed; and second, the contribution that the practice would make to the truth-seeking process of the trial must be ascertained. Acceptable rationales under both heads must be articulated before the practice can be sanctioned.

Permitting impeachment use of silence places a burden upon the exercise of a constitutional right. Under the penalty doctrine as originally articulated, this probably would have been sufficient to proscribe the practice as violative of the Constitution. As the doctrine has been modified in more recent decisions, however, a legitimate state interest in a procedure which only incidentally burdens the exercise of a constitutional right can be held to override that burden. Because impeachment use of silence is a penalty less severe that its use as substantive evidence of guilt, which the courts have uniformly prohibited, a strong argument can be made that the state's legitimate interest in ensuring the truthfulness and accuracy of trial testimony should override the smaller burden imposed on a defendant's fifth amendment rights by use of post-arrest silence for impeachment purposes.

The analysis cannot end there, however; the second requirement must also be satisfied. Upon this ground the use of postarrest silence to impeach cannot be justified. Neither precedent nor independent analysis permits the conclusion that silence upon arrest is sufficiently probative of credibility that its use for impeachment purposes would significantly advance the asserted state interest. The theory is that the failure to assert upon arrest a defense or alibi later testified to at trial is indicative that the trial testimony is false. On its own merits, it is quite tenuous. And the alternative explanation of the defendant's arrest silence-that it was an assertion of the fifth amendment-drains that silence of all force as impeaching evidence. Moreover, balanced against the marginal probative value of the silence are two problems: the difficulty of making the inconsistency determination in a given case-which is the minimum constitutional prerequisite to impeachment by a prior statement; and the degree of potential prejudice to the defendant by a jury's consideration of the silence on the issue of guilt.

The asserted state interest of truthfulness would not, therefore, be materially advanced by permitting the government to use a defendant's post-arrest silence to impeach his trial testi- 
mony. Absent this showing, the penalty concededly imposed upon the assertion of the privilege against self-incrimination by impeachment use of the silence becomes impermissible under current penalty doctrine analysis. Thus, the courts should adopt, contrary to the results reached in Agnellino, Burt, and Ramirez, a per se rule prohibiting all attempts to impeach a defendant's trial testimony by proof of his silence following arrest and Miranda warnings. 